\title{
ANALISIS USER ACCEPTANCE DAN USAGE ATAS IMPLEMENTASI SPAN PADA KEMENTERIAN KEUANGAN
}

\author{
Dwi Ari Wibawa \\ Sutiono \\ Pusdiklat Anggaran dan Perbendaharaan \\ Alamat Korespondensi:
}

INFORMASI ARTIKEL

Diterima Pertama

21 Juni 2018

Dinyatakan Diterima

21 Desember 2018

KATA KUNCI:

SPAN, pengguna, IFMIS

\begin{abstract}
ABSTRAK
The objective of this research is to analyze factors that influence user acceptance and usage of sistem perbendaharaan dan anggaran negara (SPAN) implementation at Finance Ministry of Indonesia. This research examined the impact of performance expectancy, effort expectancy, social influence, facilitating condition and managerial interventions to the attitude toward system use and symbolic adoption. This research is also examined the impact of attitude toward system use to symbolic adoption with technology trust as moderating variable. This study collected the perceptions of 259 SPAN users/operators of 8 regional office of Directorate General of Treasury and State Treasury Offices of Finance Ministry and analysed using structural equation model approach. The finding suggest that the performance expectancy, effort expectancy, social influence, facilitating condition and managerial interventions have positive and significance impact to the attitude toward system use. The finding also suggest that only social influence and facilitating condition have positive and significance impact to the symbolic adoption. Finally, the finding suggest that technology trust moderates positive and significance impact of attitude toward system use to symbolic adoption.
\end{abstract}

Tujuan dari penelitian ini adalah untuk menganalisis faktor-faktor yang mempengaruhi penerimaan dan penggunaan Sistem Perbendaharaan dan Anggaran Negara (SPAN) di Kementerian Keuangan. Penelitian ini menganalisa dampak dari harapan kinerja SPAN (performance expectancy), kemudahan penggunaan SPAN (Effort Expectancy), pengaruh sosial terhadap penggunaan SPAN (Social Influence), adanya fasilitas organisasi terhadap user SPAN (Facilitating Condition) dan intervensi pimpinan terhadap penggunaan SPAN (Managerial Intervention) terhadap sikap untuk menyukai SPAN (Attitude Toward System Use) dan menggunakan SPAN secara simbolik (Simbolic Adoption). Penelitian ini juga meneliti dampak dari sikap untuk menyukai SPAN (Attitude Toward System Use) terhadap penggunaan SPAN secara simbolik dengan kepercayaan teknologi (technology Trust) sebagai variabel moderasi. Penelitian ini mengumpulkan pendapat dari 259 pengguna SPAN / operator dari 10 kantor wilayah dari Direktorat Jenderal Perbendaharaan dan Kantor Pelayanan Perbendaharaan Negara Kemneterian Keuangan dan dianalisis menggunakan pendekatan SEM. Temuan ini menunjukkan bahwa harapan kinerja SPAN (performance expectancy), kemudahan penggunaan SPAN (Effort Expectancy), pengaruh sosial terhadap penggunaan SPAN (Social Influence), adanya fasilitas organisasi terhadap user SPAN (Facilitating Condition) dan intervensi pimpinan terhadap penggunaan SPAN (Managerial Intervention) berdampak positif dan signifikan berpengaruh positif terhadap sikap untuk menyukai SPAN (Attitude Toward System Use). Temuan ini juga menunjukkan bahwa hanya pengaruh sosial terhadap penggunaan SPAN (Social Influence), adanya fasilitas organisasi terhadap user SPAN (Facilitating Condition) berdampak positif dan signifikan terhadap penggunaan SPAN secara simbolik (Symbolic Adoption). Akhirnya, temuan menunjukkan bahwa kepercayaan terhadap SPAN (Technology Trust) mampu memoderasi hubungan sikap untuk menyukai SPAN (Attitude Toward System Use) dan menggunakan SPAN secara simbolik (Simbolic Adoption). 


\section{PENDAHULUAN}

\subsection{Latar Belakang}

Proyek Penyempurnaan Manajemen Keuangan dan Administrasi Penerimaan Pemerintah (Government Financial Management and Revenue Administration Project disingkat GFMRAP) merupakan amanat dari Peraturan Pemerintah Nomor 3 Tahun 2003 untuk melaksanakan proses transformasi menuju e-government. Salah satu bidang yang digarap oleh GFMRAP adalah manajemen keuangan publik. Dalam bidang ini, perubahan yang terbesar adalah modernisasi anggaran dan perbendaharaan negara yang diwujudkan dalam bentuk Sistem Anggaran dan Perbendaharaan Negara (SPAN). SPAN adalah bagian dari sistem informasi pengelolaan keuangan negara yang terintegrasi (integrated financial management information system disingkat IFMIS).

Perubahan mendasar dalam penerapan SPAN adalah otomasi proses bisnis pada Ditjen Anggaran dan Ditjen Perbendaharaan. SPAN akan mengotomasi proses-proses yang sifatnya pengulangan dan dilakukan secara manual. Penerapan bertujuan untuk meningkatkan efektivitas, efisiensi, akuntabilitas, dan transparansi dalam pengelolaan keuangan negara. Selain itu, dengan dukungan teknologi informasi, SPAN diharapkan dapat menyediakan

(1) perbaikan-perbaikan yang cukup signifikan dalam hal transparansi fiskal (kapasitas untuk mengakses, menganalisis dan melaporkan kegiatan-kegiatan fiskal pemerintah),

(2) sistem akuntansi dan pelaporan keuangan pemerintah yang cepat dan tepat,

(3) koneksi online ke Bank Indonesia dan jaringan perbankan lainnya yang memungkinkan pengoperasian treasury single account (TSA) yang terintegrasi dengan sistem real time gross settlement (RTGS) secara aman,

(4) prediksi kas jangka pendek dan menengah yang mampu mengoptimalkan esisiensi penyediaan dana melalui sistem perbankan,

(5) pengawasan (verifikasi) yang efektif terhadap setiap transaksi pengeluaran negara, dan

(6) sistem penganggaran terpusat yang memungkinkan unit-unit pengguna (Bappenas, departemen teknis, DPR) untuk berpartisipasi dalam proses penyusunan anggaran.

Pelaksanaan SPAN diatur dalam Peraturan Menteri Keuangan Nomor 154 Tahun 2014. Sebelum diberlakukannya peraturan ini, telah dilakukan piloting SPAN berdasarkan Peraturan Menteri Keuangan Nomor 154 Tahun 2013. Saat ini SPAN sudah diimplementasikan pada Ditjen Anggaran, Kantor Pusat Ditjen Perbendaharaan, termasuk kantor vertikalnya yang mencakup Kanwil Ditjen Perbendaharaan dan KPPN di seluruh Indonesia, dengan lebih dari 3.600 user licenses yang melayani lebih dari 24.000 satuan kerja. Investasi dalam pembangunan SPAN melibatkan biaya yang sangat besar berasal dari pinjaman luar negeri dan APBN. Selain biaya, waktu yang dibutuhkan dalam pembangunan SPAN juga relatif panjang.

Davenport (1998) menyatakan bahwa meskipun investasi dalam jumlah besar digunakan dalam pembangunan suatu sistem, namun banyak kegagalan dalam implementasi sistem tersebut dan peningkatan produktivitas yang tidak terlalu signifikan. G., Shanks dan A., Parr dalam tulisannya yang dimuat di Journal of Information Technology mengingatkan bahwa implementasi (enterprise resource planning/ERP) merupakan kegiatan yang sangat kompleks karena terjadi perubahan internal organisasi dan hal tersebut melibatkan biaya yang sangat tinggi, sehingga implementasi ERP membutuhkan pengorbanan waktu dan biaya. Realitanya 90\% implementasi ERP melebihi batas waktu dan biaya awal serta memberikan hasil yang tidak sesuai harapan. Salah satu kendala yang diungkapkan dalam implementasi ERP adalah keengganan end user (pengguna) untuk mengadopsi dan menggunakan sistem yang baru diterapkan (Barker \& Frolick, 2003; Scott \& Vessey, 2002; Umble \& Umble, 2002; Wah, 2000). Bentuk keengganan atau penolakan sistem baru dari user tersebut adalah penggunaaan sistem yang tidak sesuai harapan (Boudreau, 2002).

Berkenaan dengan hal tersebut sangat diperlukan adanya pemahaman bagaimana penerimaan pengguna (user acceptance) yang mendorong pengguna untuk memanfaatkan dan menggunakan sistem (system usage). Pemahaman mengenai faktor yang mempengaruhi user acceptance akan membantu pemerintah merencanakan langkah strategis untuk kesuksesan implementasi SPAN.

Pada bulan Desember 2015 Ditjen Perbendaharaan bekerjasama dengan Fakultas Ekonomi dan manajemen Institut Pertanian Bogor telah melakukan survei tingkat kepuasan user terhadap implementasi SPAN. Salah satu tujuan survey tersebut adalah mengukur dan mengidentifikasi tingkat kepuasan pengguna berbagai aplikasi SPAN. Hasil survei menunjukkan bahwa hasil analisis biplot keseluruhan aplikasi SPAN menunjukkan bahwa user pada wilayah Sulawesi Barat, Sulawesi Selatan, NAD, Sumatera Barat, Maluku, Jabar, Jateng dan Jatim memberikan penilaian baik, namun pengguna yang ada di wilayah Papua, Bangka Belitung, Riau, DKI Jakarta, Jambi, Papua Barat dan Bengkulu memberikan penilain kinerja yang kurang baik. Survei juga menunjukkan bahwa tingkat kepuasan pengguna aplikasi SPAN paling rendah dibandingkan dengan aplikasi OM SPAN dan aplikasi web base. Dalam laporan akhir survei disarankan untuk memperdalam kajian pada wilayah/propinsi yang 
mengindikasikan mendapatkan penilaian kinerja kurang baik.

Berdasarkan hal tersebut di atas pada penelitian ini akan dilakukan kajian untuk menganalisis faktor apa yang mempengaruhi penerimaan pengguna (user acceptance) dan penggunaan (system usage) aplikasi SPAN oleh pengguna aplikasi SPAN dengan karakteristik lingkungan penggunaan aplikasi yang bersifat mandatory. Penelitian ini difokuskan pada beberapa kantor wilayah yang mewakili sebaran kinerja layanan yang berbeda-beda mempertimbangkan survei yang telah dilakukan Ditjen Perbendaharaan dan IPB. Penelitian terhadap penerimaan dan penggunaan pengguna aplikasi SPAN menggunakan Unified Theory of Acceptance dan Use of the Technology (UTAUT) yang dikembangkan oleh Venkatesh et. al., yang dimodifikasi sesuai kebutuhan.

Penelitian ini mereplikasi hasil kajian Siska (2006) yang meneliti implementasi ERP di PT TELKOM. Penelitian ini membatasi hanya implementasi aplikasi SPAN tidak termasuk OM SPAN dan Database-nya. Lokasi kajian dibatasi hanya pada Kanwil Ditjen Perbendaharaan dan KPPN yang tersebar di wilayah Propinsi Papua, Riau, DKI Jakarta, DI Yogyakarta, Sumatera Utara, Bali, Banten, Jawa Tengah, dan Sulawesi Selatan. Delapan wilayah tersebut merepresentasikan 4 cluster wilayah hasil penelitian sebelumnya yang dilakukan oleh Ditjen Perbendaharaan dan Institut Pertanian Bogor dengan tujuan untuk menganalisis lebih mendalam terhadap faktor yang mempengaruhi penerimaan dan penggunakan user aplikasi SPAN yang menunjukkan kinerja kurang baik sampai dengan kinerja sangat baik berdasarkan survei yang sudah dilakukan sebelumnya.

Selain tujuan diatas, hasil penelitian ini diharapkan bermanfaat untuk:

1. Membantu pemerintah dalam merencanakan langkah-langkah yang harus dilakukan agar pengguna berkeinginan untuk menerima dan memanfaatkan SPAN

2. Membantu pemerintah untuk menentukan strategi pengembangan SPAN yang lebih efektif

3. Menjadi pijakan bagi penelitian SPAN selanjutnya

Ada 2 hipotesis yang diajukan dalam penelitian ini. Hipotesis 1 adalah sebagai berikut :

$\mathrm{H} 1 \mathrm{a}$ : Performance Expectancy berpengaruh attitude toward system use

$\mathrm{H} 1 \mathrm{~b}$ : Effort Expectancy berpengaruh pada attitude toward system use

$\mathrm{H} 1 \mathrm{c}$ : Social Influence berpengaruh pada attitude toward system use

H1 d : Facilitating Conditions berpengaruh pada attitude toward system use
H1 e : Managerial Interventions berpengaruh pada attitude toward system use

Sedangkan Hipotesis 2 yang diakukan adalah

$\mathrm{H} 2 \mathrm{a}$ : Performance expectancy berpengaruh langsung pada symbolic adoption SPAN

$\mathrm{H} 2 \mathrm{~b}$ : Effort expectancy berpengaruh langsung pada symbolic adoption SPAN

H2 c : Social influence berpengaruh langsung pada symbolic adoption SPAN

$\mathrm{H} 2 \mathrm{~d}$ : Facilitating conditions berpengaruh langsung pada symbolic adoption SPAN

$\mathrm{H} 2 \mathrm{e}$ : Managerial interventions berpengaruh langsung pada symbolic adoption SPAN

\section{KERANGKA TEORI DAN PENGEMBANGAN HIPOTESIS}

Untuk melakukan penelitian terhadap penerimaan dan penggunaan aplikasi SPAN, peneliti menggunakan UTAUT, yang dikembangkan oleh Venkatesh, et., al. UTAUT menggabungkan fitur-fitur yang berasal dari delapan teori penerimaan (user acceptance) teknologi terkemuka menjadi satu teori. Kedelapan teori terkemuka yang digabung dalam UTAUT adalah Theory of Reasoned Action (TRA), Technology Acceptance Model (TAM), Motivational Model (MM), Theory of Planned Behavior (TPB), Combined TAM dan TPB, Model of PC utilization (MPCU), Innovation Diffusion Theory (IDT) dan Social Cognitive Theory (SCT).

UTAUT terbukti lebih berhasil dibandingkan kedelapan teori yang lain dalam menjelaskan hingga 70 persen varian pengguna. Setelah mengevaluasi ke delapan model, Venkatesh, et. al. menemukan tujuh variabel yang nampak menjadi determinan langsung yang signifikan terhadap behavioral intention atau use behavior dalam satu atau lebih di masing-masing model. Variabel-variabel tersebut adalah performance expectancy, effort expectancy, social influence, facilitating conditions, attitude toward using technology, dan self-efficacy. Setelah melalui pengujian lebih lanjut, mereka menemukan empat variabel utama yang memainkan peran penting sebagai determinan langsung dari behavioral intention dan use behavior yaitu,

1. performance expectancy, yaitu tingkatan keyakinan user bahwa dengan menggunakan system akan membantu mereka menghasilkan performansi kerja yang maksimal

2. effort expectancy, yaitu tingkatan kemudahan yang dirasakan user dalam menggunakan sistem.

3. social influence, yaitu tingkatan kemudahan yang dirasakan user dalam menggunakan system

4. facilitating conditions, yaitu keyakinan adanya fasilitas organisasi dan teknis yang mensupport aktivitas user. 


\section{METODOLOGI PENELITIAN}

\subsection{Definisi Operasonal Variabel}

\section{Symbolic adoption}

Dalam penelitian ini symbolic adoption digunakan sebagai variabel dependen untuk mengukur user acceptance SPAN. Variabel ini menggambarkan respon emosional user terhadap SPAN (attitude toward system use).

Berdasarkan Nah, et al (2004) adopsi operasionalisasi variabel symbolic adoption untuk SPAN meliputi :

a. Antusias dalam menggunakan SPAN

b. Sangat menyukai keputusan penggunaan SPAN di tempat kerja

c. Memiliki keinginan untuk melihat pemanfaatan penuh dan pengembangan SPAN

2. Attitude Toward System Use.

Attitude toward system use diartikan sebagai kecenderungan untuk atau tidak menyukai sistem komputer, aplikasi, staffing sistem atau proses yang berhubungan dengan pemanfatan sistem aplikasi (Nah, et al, 2004). Model UTAUT tidak menempatkan attitude toward system use sebagai faktor pendorong behavior intention. Dalam sistem yang mandatory seperti implementasi SPAN, penggunaan teknologi oleh user karena pemaksaan tersebut, bukan keinginan yang muncul dari diri. Itulah mengapa variabel intention to use tidak tepat digunakan dalam lingkungan yang bersifat mandatory.

Dalam TAM attitude berasal dari perceived usefulness dan perceived ease of use dan merupakan variabel yang memunculkan behavior intention, namun berdasarkan penelitian Linders (2006) menyatakan bahwa untuk lingkungan yang dipaksakan attitude dapat memprediksi secara signifikan penerimaan dan variabel behaviour dihilangkan. Penelitian Nah, et al (2004) juga menyatakan pada lingkungan mandatory tidak ada hubungan antara behavior intention dan attitude. Hal ini menjelaskan mengapa model UTAUT tidak memasukkan variabel attitude karena venkatesh, at al (2003) mengujicobakan model pada lingkungan voluntary.

Attitude toward system use sebagai variabel yang memunculkan penerimaan juga diperkuat oleh penelitian Brown (2002) yang menyatakan bahwa attitude merupakan faktor yang berpengaruh untuk memahami penggunaan di lingkungan mandatory, karena merepresentasikan tingkat kepuasan user terhadap sistem. Untuk institusi pemerintah yang bersifat mandatory, agar sistem digunakan user maka harus mempertahankan attitude positif user.

Definisi attitude toward system use dalam penelitian adalah sikap user yang berasal dari pengaruh dalam diri user maupun pengaruh sosial terhadap penggunaan sistem SPAN sebelum akhirnya memutuskan menerima sistem.
Operasionalisasi variabel attitude toward system use adalah:

a. Menggunakan SPAN adalah ide yang bagus

b. Menyukai ide memanfaatkan SPAN untuk melaksanakan tugas (Nah, et al, 2004)

c. Bekerja dengan menggunakan SPAN menyenangkan

d. SPAN membuat bekerja lebih menarik (Venkatesh, at al, 2003)

3. Performance expectancy

Performance expentancy adalah tingkat keyakinan user bahwa dengan menggunakan sistem akan membantu mereka menghasilkan prestasi kerja yang maksimal. Performance expentancy dapat diasosiasikan dengan perceived usefulness dari model TAM. Tingkat kepercayaan bahwa sistem akan meningkatkan prestasi kerja merupakan awal munculnya attitude yang positif. Operasionalisasi variabel untuk mengukur performance expectancy adalah:

a. Merasakan manfaat SPAN bagi pekerjaan

b. Menggunakan SPAN memungkinkan penyelesaian pekerjaan lebih cepat

c. Menggunakan SPAN meningkatkan produktivitas kerja

d. Menggunakan SPAN meningkatkan kesempatan untuk naik jabatan. (Venkatesh, et.al, 2003)

\section{Effort Expectancy}

Effort expectancy didefinisikan sebagai tingkatan kemudahan yang dirasakan user dalam menggunakan sistem (Venkatesh, et al, 2003). Variabel ini diasosiasikan dengan variabel ease of use dalam TAM. Operasionalisasi variabel untuk mengukur effort expectancy, adalah:

a. Interaksi dengan SPAN jelas dan dipahami

b. Kemudahan untuk terampil menggunakan SPAN

c. Merasakan SPAN mudah digunakan

d. Kemudahan belajar menggunakan SPAN (Venkatesh, et al, 2003)

Menurut Clark, Jones dan Zmud dalam menggunakan sistem yang terintegrasi seperti SPAN, ada dua hal yang harus dipahami user:

a. Pemahaman mengenai sistem software Kemudahan dan sedikitnya usaha dalam mendalami software akan mendorong user untuk menerima sistem yang kompleks.

b. Pemahaman mengenai alur proses

Pemahaman user mengenai struktur kerja mutlak diperlukan dalam memahami software. Seorang user yang mengetahui ketergantungan user lain mengenai data yang diinputnya akan meningkatkan tanggungjawabnya akan akurasi data. Kemudahan dan sedikitnya usaha dalam memahami posisi akan mendorong user menerima sistem yang kompleks.

Sehingga operasionalisasi variabel tersebut ditambahkan item: 
a. Mengetahui posisi dirinya dalam alur penggunaan SPAN

b. Mudah memahami dampak yang terjadi jika tidak melaksanakan pekerjaannya.

\section{Social Influence}

Social Influence adalah tingkat persepsi seseorang bahwa pihak lain percaya bahwa sebaiknya menggunakan sistem baru (Venkatesh et. al., 2003). Social influence mempengaruhi perilaku individu melalui tiga mekanisme (Venkatesh and Davis 2000), yaitu

a. Compliance, ketika seseorang melakukan sesuatu bukan karena keyakinan akan kebenaran isinya, tapi karena mengharapkan adanya hadiah atau hukuman yang ia hindari.

b. Identification, ketika seseorang menerima pengaruh karena ia ingin membangun atau menjaga hubungan baik dengan orang lain atau kelompok tertentu

c. Internalization, ketika seseorang menerima pengaruh karena hal itu sesuai dengan nilainilai hidupnya.

Operasionalisasi variabel untuk mengukur social influence adalah :

a. Seseorang yang mempengaruhi perilaku kerja berfikir bahwa saya harus menggunakan SPAN

b. Seseorang yang penting bagi pekerjaan berfikir bahwa saya harus menggunakan SPAN

c. Bantuan pimpinan dalam mendukung penggunaan SPAN

d. Secara umum organisasi mendukung penggunaan SPAN

\section{Facilitating Conditions}

Facilitating condition adalah keyakinan adanya fasilitas organisasi dan teknis yang mensupport aktivitas user (Venkatesh, et al 2003). Operasionalisasi variabel untuk mengukur facilitating conditions adalah :

a. Adanya sarana dan prasarana yang dibutuhkan untuk menggunakan SPAN

b. Adanya pengetahuan user yang dibutuhkan untuk menggunakan SPAN

c. Kompabilitas SPAN dengan sistem lain yang digunakan

d. Ada sekelompok/orang yang siap membantu mengatasi kesulitan SPAN

7. Managerial Interventions

Managerial interventions adalah tindakan spesifik manajemen dan kebijakan yang dilakukan institusi untuk mempengaruhi penerimaan teknologi oleh user. Zmud (1984) memposisikan pentingnya sikap pimpinan terhadap suksesnya implementasi suatu sistem baru. Inovasi membutuhkan perubahan lokasi dan posisi penting sumber daya perusahaan, tanpa adanya dukungan manajemen puncak akan sulit melaksanakannya. (Agarwal, 2000).
Dari beberapa penelitian menunjukkan bahwa managerial intervention yang penting dalam dukungan penggunaan teknologi adalah berkembangnya budaya kerja yang kondusif untuk pembelajaran dan penelitian. Komitmen manajerial juga ditunjukkan dalam berbagai cara seperti melalui aturan yang tepat, dorongan penggunaan teknologi atau melalui jaminan mengenai ketersediaan sumber daya (Agarwal, 2000).

Untuk menciptakan iklim kerja yang kondusif para manajer dapat menyediakan insentif bagi penggunaan teknologi. User akan menunjukkan tingkat yang lebih tinggi dari pemanfaatan sistem dengan adanya insentif ini. (Zmud, 1982; Scott dan Bruce, 1994 dalam Agarwal, 2000) .

Berdasarkan beberapa hasil penelitian tersebut, operasional variabel untuk mengukur managerial interventions adalah :

a. Adanya restrukturisasi organisasi yang memudahkan posisi user dalam komunikasi dan koordinasi penggunaan user

b. Adanya peraturan yang memaksakan penggunaan SPAN

c. Adanya training secara berkala sesuai kebutuhan user.

d. Adanya kesempatan untuk memperdalam kemampuan user dengan memfasilitasi pembelajaran dan penelitian

e. Adanya insentif khusus bagi user yang menggunakan SPAN

8. Technology Trust.

Trust adalah keyakinan akan sesuatu, keinginan untuk bergantung pada sesuatu, meskipun dalam kondisi yang sulit seperti kurangnya jaminan atau pun kekuatan untuk melakukan suatu kinerja. Trust juga berarti pemahaman bersama mengenai hubungan dan sesuatu yang harus diselesaikan bersama. Lankton dan McKnight (2005) menyatakan trust in technology merupakan konsep yang penting ketika sistem menjadi kompleks dan sulit dimengerti. Dalam penelitian ini trust diartikan sebagai tingkat kepercayaan user terhadap kemampuan SPAN untuk memberikan bagi individu dan organisasi.

Operasionalisasi variabel technology trust adalah sebagai berikut :

a. Selalu menyadari bahwa SPAN mampu menyelesaikan tugas yang berat

b. SPAN digunakan dalam mengerjakan tugastugas utama

c. SPAN dapat diandalkan untuk mengerjakan tugas-tugas penting.

3.2. Metode Analisis Data

Dalam penelitian ini penulis menggunakan metode analisis data SEM.Structural Equation Model (SEM) merupakan sekumpulan teknikteknik statistik yang memungkinkan pengujian sebuah rangkaian hubungan secara simultan. Model hubungan yang dibangun dapat antara satu atau beberapa variabel dependen dengan satu atau 
beberapa variabel independen. Masing-masing variable dependen dan independen dapat berbentuk faktor (atau konstruk yang dibangun dari beberapa variabel indikator). Sesungguhnya pemodelan dengan persamaan struktural telah dikenal luas dalam penelitian-penelitian manajemen, melalui berbagai macam nama antara lain: causal modeling, causal analysis simultaneous equations modeling atau analisis struktur kovariance. Seringkali SEM disebut juga sebagai path analysis atau confirmatory factor analysis. Pengujian hipotesa menggunakan alat bantu software LISREL.

\section{HASIL PENELITIAN}

Dari hasil analisis data didapatkan hasil uji hipotesis sebagaimana tampak pada berikut ini.

Hasil Uji Hipotesis

\begin{tabular}{|c|c|c|c|c|c|}
\hline \multicolumn{2}{|c|}{ Hipotesis } & Koefisien & $\begin{array}{c}\mathrm{T} \\
\text { Hitung }\end{array}$ & Keterangan & Interpretasi \\
\hline $\mathrm{H} 1 \mathrm{a}$ & $\begin{array}{l}\mathrm{PE} \\
\rightarrow \\
\mathrm{AT}\end{array}$ & 0.34 & 9.72 & Significant & $\begin{array}{l}\text { PE } \\
\text { berpengaruh } \\
\text { significant } \\
\text { terhadap AT. } \\
\text { semakin kuat } \\
\text { PE akan } \\
\text { meningkatka } \\
\text { n AT }\end{array}$ \\
\hline H1b & $\begin{array}{l}\mathrm{EE} \\
\rightarrow \\
\mathrm{AT}\end{array}$ & 0.43 & 11.93 & Significant & $\begin{array}{l}\text { EE } \\
\text { berpengaruh } \\
\text { significant } \\
\text { terhadap AT. } \\
\text { semakin kuat } \\
\text { EE akan } \\
\text { meningkatka } \\
\text { n AT }\end{array}$ \\
\hline H1c & $\begin{array}{l}\mathrm{SI} \\
\rightarrow \\
\mathrm{AT}\end{array}$ & 0.12 & 3.47 & Significant & $\begin{array}{l}\text { SI } \\
\text { berpengaruh } \\
\text { significant } \\
\text { terhadap AT. } \\
\text { semakin kuat } \\
\text { SI akan } \\
\text { meningkatka } \\
\text { n AT }\end{array}$ \\
\hline H1d & $\begin{array}{l}\mathrm{FC} \\
\rightarrow \\
\mathrm{AT}\end{array}$ & 0.14 & 3.86 & Significant & $\begin{array}{l}\text { FC } \\
\text { berpengaruh } \\
\text { significant } \\
\text { terhadap AT. } \\
\text { semakin kuat } \\
\text { FC akan } \\
\text { meningkatka } \\
\text { n AT }\end{array}$ \\
\hline H1e & $\begin{array}{l}\mathrm{MI} \\
\rightarrow \\
\mathrm{AT}\end{array}$ & 0.18 & 4.73 & Significant & $\begin{array}{l}\text { MI } \\
\text { berpengaruh } \\
\text { significant } \\
\text { terhadap AT. } \\
\text { semakin kuat } \\
\text { MI akan } \\
\text { meningkatka } \\
\text { n AT }\end{array}$ \\
\hline $\mathrm{H} 2 \mathrm{a}$ & $\begin{array}{l}\mathrm{PE} \\
\rightarrow \\
\mathrm{SA}\end{array}$ & 0.03 & 0.34 & $\begin{array}{l}\text { Tidak } \\
\text { Significant }\end{array}$ & $\begin{array}{l}\text { PE tidak } \\
\text { berpengaruh } \\
\text { significant } \\
\text { terhadap SA. }\end{array}$ \\
\hline $\mathrm{H} 2 \mathrm{~b}$ & $\begin{array}{l}\mathrm{EE} \\
\rightarrow \\
\mathrm{SA}\end{array}$ & 0.09 & 1.28 & $\begin{array}{l}\text { Tidak } \\
\text { Significant }\end{array}$ & $\begin{array}{l}\text { EE tidak } \\
\text { berpengaruh } \\
\text { significant } \\
\text { terhadap SA }\end{array}$ \\
\hline $\mathrm{H} 2 \mathrm{c}$ & SI & 0.13 & 2.49 & Significant & SI \\
\hline
\end{tabular}

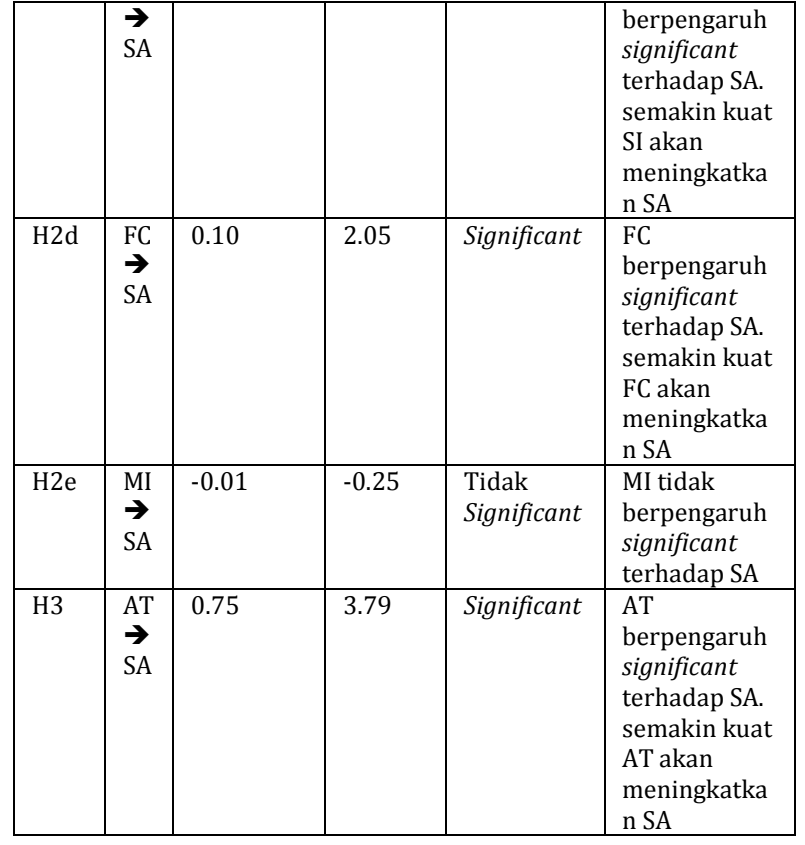

Berdasarkan tujuan penelitian dan kerangka pemikiran konseptual, ada dua hipotesis yang diajukan dalam penelitian. Hipotesis 1 adalah sebagai berikut :

H1a : Performance Expectancy berpengaruh attitude toward system use

$\mathrm{H1b}$ : Effort Expectancy berpengaruh pada attitude toward system use

H1c : Social Influence berpengaruh pada attitude toward system use

H1d : Facilitating Conditions berpengaruh pada attitude toward system use

H1e : Managerial Interventions berpengaruh pada attitude toward system use

Hasil analisisis terhadap hipotesis tersebut dijelaskan sebagai berikut:

$\mathrm{H}_{1 \mathrm{a}}$ : PE memiliki hubungan langsung dan positif dengan AT.

Hasil uji-t pada output SEM menunjukkan nilai t-hitung(9.72) lebih besar dari t-tabel $(1,96)$ artinya hipotesis diterima, PE berpengaruh langsung dan positif terhadap AT. Semakin baik keseuaian PE maka akan meingkatkan AT

$\mathrm{H}_{1 \mathrm{~b}}$ : Struktur EE memiliki hubungan langsung dan positif dengan AT.

Hasil uji-t pada output SEM menunjukkan nilai t-hitung(11.93) lebih besar dari t-tabel $(1,96)$ artinya hipotesis diterima, EE berpengaruh langsung dan positif terhadap AT. Semakin baik keseuaian EE maka akan meingkatkan AT

$\mathrm{H}_{1 \mathrm{c}}$ : SI memiliki hubungan langsung dan positif dengan AT.

Hasil uji-t pada output SEM menunjukkan nilai t-hitung(3.47) lebih besar dari t-tabel $(1,96)$ artinya hipotesis diterima, SI 
berpengaruh langsung dan positif terhadap AT. Semakin baik keseuaian SI aka akan meingkatkan AT

$\mathrm{H}_{1 \mathrm{~d}}$ FC memiliki hubungan langsung dan positif dengan AT.

Hasil uji-t pada output SEM menunjukkan nilai t-hitung(3.86) lebih besar dari t-tabel $(1,96)$ artinya hipotesis diterima, FC berpengaruh langsung dan positif terhadap AT. Semakin baik keseuaian FC maka akan meingkatkan AT

$\mathrm{H}_{1 \mathrm{e}}$ : MI memiliki hubungan langsung dan positif dengan AT.

Hasil uji-t pada output SEM menunjukkan nilai t-hitung(4.73) lebih besar dari t-tabel $(1,96)$ artinya hipotesis diterima, MI berpengaruh langsung dan positif terhadap AT. Semakin baik keseuaian MI maka akan meingkatkan AT.

Berdasarkan hasil analisa diatas dapat disimpulkan bahwa H1a, H1b, H1c, H1d, H1e diterima. Kesimpulan tersebut menunjukkan bahwa variabel performance expectancy, effort expectancy, social influence, facilitating condition dan managerial intervention mempunyai pengaruh langsung terhadap variabel attitude toward system use. Hal ini berarti bahwa untuk penerimaan SPAN di lingkungan mandatory, harapan penggunaan SPAN akan meningkatkan performa kerja, harapan user SPAN untuk memahami penggunaan SPAN dengan sedikit upaya, adanya pengaruh sosial dalam lingkungan mereka, kondisi lingkungan dengan berbagai fasilitas yang disediakan organisasi dan intervensi pimpinan menjadi faktor yang membentuk sikap untuk menerima aplikasi SPAN

Dari masing-masing variabel tersebut terdapat beberapa indikator yang mempunyai pengaruh yang paling dominan dibanding indikator lain. Indikator tersebut dapat dijelaskan sebagai berikut :

a. Pernyataan merasakan manfaat SPAN bagi pekerjaan merupakan indikator yang paling dominan dalam pembentukan performance expectancy dibanding indikator lain seperti penggunaan SPAN memungkinkan penyelesaian pekerjaan lebih cepat, penggunaan SPAN meningkatkan produktivitas kerja dan penggunaan SPAN meningkatkan kesempatan naik jabatan. Hal ini berarti merasakan manfaat SPAN dalam menggunakan SPAN adalah faktor yang paling berperan dalam membentuk variabel tingkat keyakinan user bahwa menggunakan sistem akan membantu operator menghasilkan prestasi maksimal

b. Pernyataan mengetahui posisi diri dalam alur penggunaan SPAN merupakan indikator yang paling dominan dalam pembentukan effort expentancy dibanding indikator lain seperti interaksi dengan SPAN jelas dan mudah dipahami, kemudahan untuk terampil menggunakan SPAN, merasakan SPAN mudah digunakan, kemudahan belajar menggunakan SPAN dan mudah memahami dampak yang terjadi jika tidak melaksanakan pekerjaan . Hal ini dapat diartikan bahwa mengetahui posisi diri dalam alur penggunaan SPAN mempunyai pengaruh paling dominan dalam membentuk variabel tingkat kemudahan yang dirasakan operator dalam menggunakan Aplikasi SPAN.

c. Pernyataan secara umum organisasi mendukung penggunaan SPAN merupakan indikator yang paling dominan dalam pembentukan Social Influency dibanding indikator lain seperti faktor seseorang yang mempengaruhi perilaku kerja berfikir harus menggunakan SPAN, seseorang yang penting bagi pekerjaan berfikir saya harus menggunakan SPAN, bantuan atasan dalam mendukung penggunaan SPAN, user yang menggunakan SPAN lebih bergengsi. Hal ini berarti harapan bahwa organisasi mendukung penggunaan SPAN adalah faktor yang paling dominan dalam membentuk variabel kesadaran operator mengenai adanya pengaruh orang lain dalam menggunakan SPAN

d. Pernyataan adanya sarana dan prasarana yang dibutuhkan untuk menggunakan SPAN merupakan faktor paling dominan dalam Facilitating Condition bila dibanding kan indikator lain seperti adanya pengetahuan user untuk menggunakan SPAN, kompatibilitas SPAN dengan sistem lain. Hal ini berarti adanya sarana dan prasarana yang dibutuhkan untuk menggunakan SPAN adalah faktor paling dominan dalam membentuk variabel keyakinan adanya fasilitas organisasi dan teknis men-support operator SPAN.

e. Pernyataan adanya restrukturisasi organisasi yang memudahkan posisi user dalam komunikasi dan koordinasi merupakan faktor paling dominan dalam variabel managerial intervention dibanding indikator lain seperti peraturan pimpinan organisasi yang memaksakan penggunaan SPAN, adanya training secara berkala, kesempatan organisasi untuk memperdalam kemampuan user dengan memfasilitasi pembelajaran dan penelitian dan adanya insentif khusus bagi user yang menggunakan SPAN. Hal ini berarti adanya restrukturisasi organisasi yang memudahkan posisi user dalam komunikasi dan koordinasi adalah faktor paling dominan dalam membentuk dalam membentuk tindakan spesifik managemen dan peraturan yang dilakukan organisasi untuk mempengaruhi penerimaan SPAN. 
Hasil penelitian ini sesuai dengan hasil penelitian yang memasukkan performance expectancy, effort expectancy, social influence, facilitating conditions dan managerial interventions (venkatesh, et.al, 2003 dan agarwal, 1999) sebagai faktor yang mempengaruhi penerimaan sistem.

Hipotesis 2 yang diajukan adalah

$\mathrm{H} 2 \mathrm{a}$ : Performance expectancy berpengaruh langsung pada symbolic adoption SPAN

$\mathrm{H} 2 \mathrm{~b}$ : Effort expectancy berpengaruh langsung pada symbolic adoption SPAN

$\mathrm{H} 2 \mathrm{c}$ : Social influence berpengaruh langsung pada symbolic adoption SPAN

$\mathrm{H} 2 \mathrm{~d}$ : Facilitating conditions berpengaruh langsung pada symbolic adoption SPAN

$\mathrm{H} 2 \mathrm{e}$ : Managerial interventions berpengaruh langsung pada symbolic adoption SPAN

Berdasarkan hasil uji hipotesis didapatkan hasil sebagai berikut

$\mathrm{H}_{2 a}$ : PE memiliki hubungan langsung dan positif dengan SA.

Hasil uji-t pada output SEM menunjukkan nilai t-hitung $(0.34)$ lebih kecil dari t-tabel $(1,96)$ artinya hipotesis ditolak, PE tidak berpengaruh langsung dan positif terhadap SA.

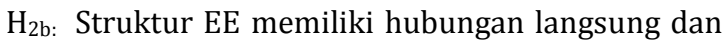
positif dengan SA.

Hasil uji-t pada output SEM menunjukkan nilai t-hitung(1.28) lebih kecil dari t-tabel $(1,96)$ artinya hipotesis ditolak, EE tidak berpengaruh langsung dan positif terhadap SA.

$\mathrm{H}_{2 c:}$ SI memiliki hubungan langsung dan positif dengan SA.

Hasil uji-t pada output SEM menunjukkan nilai t-hitung(2.49) lebih besar dari t-tabel $(1,96)$ artinya hipotesis diterima, SI berpengaruh langsung dan positif terhadap SA. Semakin baik keseuaian SI aka akan meingkatkan SA

$\mathrm{H}_{2 \mathrm{~d}} \mathrm{FC}$ memiliki hubungan langsung dan positif dengan SA.

Hasil uji-t pada output SEM menunjukkan nilai t-hitung(2.05) lebih besar dari t-tabel $(1,96)$ artinya hipotesis diterima, FC berpengaruh langsung dan positif terhadap SA. Semakin baik keseuaian FC maka akan meingkSAkan SA

$\mathrm{H}_{2 \mathrm{e}}$ : MI memiliki hubungan langsung dan positif dengan SA.

Hasil uji-t pada output SEM menunjukkan nilai t-hitung $(-0.25)$ lebih kecl dari t-tabel $(1,96)$ artinya hipotesis ditolak, MI tidak berpengaruh langsung dan positif terhadap SA.
Berdasarkan hasil analisa di atas maka dapat disimpulkan bahwa H2a, H2b, H2e ditolak sedangkan $\mathrm{H} 2 \mathrm{c}$ dan $\mathrm{H} 2 \mathrm{~d}$ diterima

Hal tersebut menunjukkan bahwa dalam konteks SPAN, tingkat keyakinan user bahwa menggunakan SPAN akan menghasilkan prestasi maksimal (Performance Expectancy), Tingkat kemudahan yang dirasakan user dalam menggunakan SPAN (Effort Expectancy), dan Tindakan spesifik manajemen dan peraturan yang dilakukan organisasi untuk mempengaruhi penerimaan SPAN (Managerial Intervention) tidak berpengaruh langsung terhadap penerimaan SPAN secara mental (Symbolic Adobtion). Sedangkan variabel kesadaran seseorang mengenai adanya pengaruh orang lain (social Influence) dan keyakinan adanya fasilitas organisasi dan teknis mensupport aktivitas user (Facilitating Condition) berpengaruh langsung terhadap terhadap penerimaan SPAN secara mental (Symbolic Adobtion).

Hal ini dapat dijelaskan bahwa SPAN adalah aplikasi yang bersifat mandatory penggunaannya. Sebagai aplikasi yang bersifat mandatory agar penerimaan secara mental berlangsung baik yang selanjutnya akan menjadikan user menggunakan SPAN maka harus ada faktor eksternal yaitu dari lingkungan berupa pengaruh orang lain yang menggunakan sistem dan adanya keyakinan bahwa organisasi dan teknis memberikan support terhadap aktivitas user.

Pada Tabel 1 sebagaimana lampiran dapat dilihat bahwa ada perbedaan pengaruh masingmasing variabel bebas terhadap variabel dependent untuk setiap wilayah responden. Hasil uji setiap propinsi dapat dilihat pada keterangan berikut:

1. Pada Kanwil Propinsi Bali ternyata variabel Performance Expectancy dan Social Influences tidak berpengaruh langsung terhadap Attitude toward system use. Pengaruh terbesar yang mempengaruhi Attitude toward system use adalah variabel Effort Expectancy, sedangkan variabel yang berpengaruh terbesar terhadap Simbolic adoption adalah variabel Performance expectancy

2. Pada Kanwil propinsi Jawa Tengah Facilitating conditions tidak berpengaruh langsung terhadap Attitude toward system use. Pengaruh terbesar yang mempengaruhi Attitude toward system use adalah variabel Managerial intervention, sedangkan variabel yang berpengaruh terbesar terhadap Simbolic Adoption adalah variabel Facilitating Conditions

3. Pada Kanwil Propinsi Banten variabel Managerial Interventions tidak berpengaruh terhadap Simbolic Adoptions dan Social Influence tidak berpengaruh terhadap Attitude Toward system Use. Pengaruh terbesar yang mempengaruhi Attitude toward system use 
adalah variabel Effort Expectancy, sedangkan variabel yang berpengaruh terbesar terhadap Simbolic Adoption adalah variabel Social Influence

4. Pada Kanwil Propinsi Papua variabel Efforts Expectancy dan Performance Expectancy tidak berpengarh terhadap Symbolic adoption. Pengaruh terbesar yang mempengaruhi Attitude toward system use adalah variabel Performance Expectancy, sedangkan variabel yang berpengaruh terbesar terhadap Simbolic Adoption adalah variabel Facilitating Conditions

Pada Tabel 2 sebagaimana lampiran dapat dilihat bahwa ada perbedaan pengaruh masing-masing variabel bebas terhadap variabel dependent untuk setiap wilayah responden. Hasil uji setiap propinsi dapat dilihat pada keterangan berikut :

1. Pada Kanwil Propinsi Jakarta ternyata variabel Effort expectancy tidak berpengaruh symbolic adobtion dan Social Influences tidak berpengaruh langsung terhadap Attitude toward system use. Pengaruh terbesar yang mempengaruhi Attitude toward system use adalah variabel Performance Expectancy, sedangkan variabel yang berpengaruh terbesar terhadap Simbolic adoption adalah variabel Performance expectancy

2. Pada Kanwil Propinsi Riau variabel Performace Expectancy tidak berpengaruh langsung terhadap Attitude toward system use. Pengaruh terbesar yang mempengaruhi Attitude toward system use adalah variabel Effort Expectancy, sedangkan variabel yang berpengaruh terbesar terhadap Simbolic adoption adalah variabel Efforts Expectancy

3. Pada Kanwil Propinsi Sulawesi Selatan variabel Facilitating Condition tidak berpengaruh terhadap Simbolic adoptions. Pengaruh terbesar yang mempengaruhi Attitude toward system use adalah variabel Performance Expectancy, sedangkan variabel yang berpengaruh terbesar terhadap Simbolic adobtion adalah variabel Performance expectancy

Pada Tabel 3 sebagaimana lampiran dapat dilihat bahwa ada perbedaan pengaruh masing-masing variabel bebas terhadap variabel dependent untuk setiap wilayah responden. Hasil uji setiap propinsi dapat dilihat pada keterangan berikut :

1. Pada Kanwil Propinsi Sumatera Utara ternyata variabel Managerial Intervention tidak berpengaruh langsung terhadap Attitude toward system use. Pengaruh terbesar yang mempengaruhi Attitude toward system use adalah variabel Efforts Expectancy, sedangkan variabel yang berpengaruh terbesar terhadap Simbolic adobtion adalah variabel Social Influence

2. Pada Kanwil Propinsi Tanjung Pinang variabel Facilitating Condition tidak berpengaruh langsung terhadap Attitude toward system use dan varaiabel Managerial Intervention tidak berpengaruh terhadap Symbolic adoption. Pengaruh terbesar yang mempengaruhi Attitude toward system use adalah variabel Social Influence, sedangkan variabel yang berpengaruh terbesar terhadap Simbolic adoption adalah variabel Social Influence

3. Pada Kanwil Propinsi Yogyakarta variabel Social Influence tidak berpengaruh terhadap Simbolic adoptions. Pengaruh terbesar yang mempengaruhi Attitude toward system use adalah variabel Social Influence, sedangkan variabel yang berpengaruh terbesar terhadap Simbolic adoption adalah variabel facilitating conditions

\section{KESIMPULAN DAN SARAN}

Berdasarkan hasil analisis dan pengujian hipotesis dapat ditarik kesimpulan sebagai berikut

1. Performance expectancy, effort expectancy, facilitating condition, social influence dan managerial influence adalah faktor yang memengaruhi attitude toward technology use.

2. facilitating condition dan social influence adalah faktor yang mempengaruhi symbolic adoption.

3. Performance expectancy, effort expectancy, dan managerial influence adalah faktor yang tidak mempengaruhi symbolic adoption.

4. Attitude toward technology use mempengaruhi symbolic adoption.

5. Technology trust adalah faktor yang memoderasi hubungan attitude toward technology use dengan symbolic adoption.

6. Faktor yang paling mempengaruhi sikap user untuk menerima Aplikasi SPAN adalah pertama, SPAN bermanfaat dalam pekerjaan, kedua, operator menginginkan kejelasan posisi dirinya dalam penggunaan SPAN, ketiga, operator membutuhkan dukungan organisasi dalam penggunaan SPAN, keempat, operator membutuhkan sarana dan prasarana yang mendukung penggunaan SPAN dan kelima, operator sangat membutuhkan struktur organisasi yang memudahkan operator dalam melakukan komunikasi maupun koordinasi dalam penggunaan SPAN.

7. Faktor yang paling rendah mempengaruhi sikap user untuk menerima Aplikasi SPAN adalah pertama, penggunaan SPAN meningkatkan kesempatan naik jabatan, kedua, interaksi dengan SPAN jelas dan mudah dipahami, ketiga, user yang menggunakan SPAN lebih bergengsi dari yang tidak menggunakan, keempat, kompatbilitas SPAN dengan sistem lain yang digunakan, dan kelima adalah, insentif khusus bagi user yang menggunakan SPAN. 
8. Faktor yang paling besar mempengaruhi harapan operator dalam pemanfaatan secara lengkap dan pengembangan SPAN pada masa mendatang adalah dukungan organisasi dalam penggunaan SPAN dan dukungan sarana serta prasarana yang dibutuhkan untuk penggunaan SPAN.

9. Keyakinan operator terhadap kemampuan SPAN dalam melakukan tugas utama DJA dan DJPB mampu memoderasi sikap operator yang baik terhadap SPAN dalam pemanfaatan SPAN secara lengkap dan pengembangan SPAN pada masa mendatang.

10. Perbedaan antar wilayah terkait penerimaan operator terhadap Aplikasi SPAN.

\section{IMPLIKASI DAN KETERBATASAN}

Dalam penelitian ini, peneliti menemukan berbagai keterbatasan dalam melakukan penelitian. Adapun keterbatasan penelitian yang ada adalah :

1. Sampel

Jumlah sampel dalam penelitian ini sudah memenuhi jumlah minimal sampel yang dibutuhkan, namun kemungkinan ini akan menghasilkan data yang lebih baik jika dilakukan pada populasi dan sampel yang lebih besar

2. Responden

Dalam penelitian ini data diperoleh dari responden berdasarkan persepsi operator terhadap implementasi SPAN, terkadang jawaban yang diberikan tidak menunjukkan keadaan sesungguhnya.

Berdasarkan pembahasan pada bab sebelumnya, agar penerimaan user SPAN oleh operator semakin baik, maka peneliti dapat memberikan saran sebagai berikut:

1. Untuk meningkatkan penerimaan user terhadap aplikasi SPAN, maka pengembang aplikasi SPAN harus memperhatikan faktor-faktor yang berpengaruh langsung yaitu social influence dan facilitating condition.

2. Social influence terdiri dari pengaruh orang penting dalam kantor yang mempengaruhi operator dalam penerimaan SPAN, dukungan kepala kantor dalam penggunaan SPAN, dan dukungan organisasi dalam penggunaan SPAN. Berdasarkan komentar dari responden, harapan mereka terkait variabel ini adalah pembentukan forum operator SPAN, akses komunikasi langsung ketika terdapat kesulitan dalam penggunaan SPAN,

3. Facilitating condition terdiri dari ketersediaan sarana dan prasarana yang dibutuhkan dalam penggunaan SPAN, pengetahuan operator yang dibutuhkan dalam penggunaan SPAN, dan adanya sekelompok orang khusus yang siap membantu mengatasi kesulitan SPAN. Harapan operator terkait variable ini adalah peningkatan kapasitas server, jaringan listrik, penyediaan hardware computer, jaringan internet, pemeliharaan aplikasi tidak pada hari kerja, pelatihan operator yang intensif dan berkala, menu dalam aplikasi SPAN yang lebih user friendly, penyediaan manual book yang update dan komprehensif.

4. Untuk meningkatkan sikap operator SPAN dalam menggunakan Aplikasi SPAN, Ditjen Perbendaharaan harus memperhatikan beberapa indikator di bawah ini. Indikator di bawah ini berdasarkan hasil analisa memberikan kontribusi paling besar dalam membentuk masing-masing variabel :

a. Meningkatkan sikap bahwa operator SPAN merasakan manfaat SPAN bagi pekerjaan. Indikator ini mempunyai kontribusinya paling besar untuk membentuk keyakinan bahwa Aplikasi SPAN membantu menghasilkan prestasi maksimal.

b. Meningkatkan pemahaman operator SPAN sehingga operator SPAN mengetahui posisi dirinya dalam alur proses penggunaan SPAN. Indikator ini mempunyai kontribusi paling besar dalam membentuk tingkat kemudahan dalam menggunakan SPAN. Pemahaman terhadap kedudukan dirinya dalam alur penggunaan SPAN ini penting, dengan pemahaman ini operator akan bertanggung jawab terhadap pekerjaannya, karena keterlambatan pada dirinya akan mengakibatkan keterlambatan pada pekerjaan lain.

c. Ditjen Perbendaharaan harus memberikan dukungan dalam penggunaan Aplikasi SPAN. Indikator ini merupakan indikator yang memberikan kontribusi paling besar untuk membentuk variabel kesadaran seseorang mengenai adanya pengaruh orang lain

d. Ditjen perbendaharaan juga harus terus meningkatkan penyediaan sarana dan prasaran yang dibutuhkan dalam menggunakan SPAN. Indikator ini adalah indikator yang paling banyak memberikan kontribusi dalam membentuk keyakinan adanya fasilitas organisasi dan teknis

e. Ditjen Perbendaharaan harus melakukan restrukturisasi organisasi yang memudahkan operator SPAN dalam koordinasi dan komunikasi. Indikator ini juga merupakan indikator yang paling banyak memberikan kontribusi dalam membentuk keyakinan operator SPAN bahwa organisasi melakukan tindakan spesifik manajemen atau peraturan yang mempengaruhi penerimaan SPAN

5. Untuk meningkatkan harapan operator dalam pemanfaatan secara lengkap dan pengembangan SPAN maka perlu diperhatian 
beberapa indikator berikut, indikator tersebuat adalah :

a. Meningkatkan sarana dan prasaran yang dibutuhkan untuk menggunakan SPAN. Indikator ini adalah indikator yang besar memberikan kontribusi dalam membentuk keyakinan adanya fasilitas organisasi dan teknis yang mendukung aktifitas operator SPAN.

b. Meningkatkan dukungan organisasi dalam penggunaan SPAN. Indikator ini adalah indikator yang mempunyai kontribusi terbesar dalam membentuk kesadaran adanya pengaruh orang lain dalam menggunakan SPAN

6. Berdasarkan hasil analisis data per wilayah yang menunjukkan kecenderungan pengaruh yang berbeda untuk setiap variabel, maka disarankan untuk meningkatkan penerimaan operator di masing-masing kanwil dengan melihat kecenderungan pengaruh tersebut, antara lain :

a. Pada Kanwil Propinsi Bali untuk meningkatkan kecenderungan untuk menyukai aplikasi SPAN dapat dilakukan dengan meningkatkan Effort expectancy, sedangkan untuk meningkatkan penerimaan SPAN secara mental dapat dilakukan dengan meningkatkan Performance Expectancy. Berdasarkan saran operator SPAN pada Kanwil Propinsi Bali, hal ini dapat dilakukan dengan :

1) update aplikasi SPAN sehingga sesuai dengan kebutuhan user

2) Penyederhanaan menu dalam Aplikasi SPAN

3) Dilakukan komunikasi dengan daerah terlebih dahulu ketika akan melakukan maintenance aplikasi

b. Pada Kanwil Propinsi Jawa Tengah untuk meningkatkan kecenderungan untuk menyukai aplikasi SPAN dapat dilakukan dengan meningkatkan Managerial Intervention, sedangkan untuk meningkatkan penerimaan SPAN secara mental daoat dilakukan dengan meningkatkan Facilitating Conditions. Berdasarkan saran operator SPAN pada Kanwil Propinsi Jawa Tengah, hal ini dapat dilakukan dengan :

1) Diadakan pelatihan skala berkala oleh kantor pusat

2) Komunikasi yang intens dengan daerah misalnya ketika ada perbaikan di pusat

3) Penambahan bandwith dan diberikan akses langsung komunikasi ke pusat jika ada gangguan

4) Penambahan user
5) Perubahan tatacara upload data supllier sehingga tidak perlu dilakukan satu persatu

6) Implementasi SAKTI segera dilakukan pada Kementerian/Lembaga

c. Pada Kanwil Propinsi Banten untuk meningkatkan kecenderungan untuk menyukai aplikasi SPAN dapat dilakukan dengan meningkatkan Effort Expectancy, sedangkan untuk meningkatkan penerimaan SPAN secara mental daoat dilakukan dengan meningkatkan Social Influence. Berdasarkan saran operator SPAN pada Kanwil Propinsi Banten, hal ini dapat dilakukan dengan :

1) Perlu penambahan karwas uang muka pada Front Office untuk validasi SPM GUP Satker

2) Penyempurnaan menu SPAN, seperti penolakan tagihan di user Middle Office

3) Penyederhanaan proses bisnis SPAN, seperti percepatan request pelaporan yang akan digunakan untuk penyusunan LKPP

4) Agar dipertimbangkan user administrator tidak berada di kepala kantor, karena banyak sekali pekerjaan teknis cukup ditangani di level pelaksana

d. Pada Kanwil Propinsi Papua untuk meningkatkan kecenderungan untuk menyukai aplikasi SPAN dapat dilakukan dengan meningkatkan Performance Expectancy, sedangkan untuk meningkatkan penerimaan SPAN secara mental dapat dilakukan dengan meningkatkan Facilitating Condition. Berdasarkan saran operator SPAN pada Kanwil Propinsi Papua, hal ini dapat dilakukan dengan :

1) Diadakan pelatihan skala berkala terhadap operator SPAN

2) Perbaikan menu pada SPAN, seperti tampilan opsi filter data ditampilkan lebih lengkap.

3) Sosialisasi trouble shooting masingmasing seksi

4) Peningkatan kecepatan akses, keterbatasan penarikan akses seringkali membuat lamanya waktu waktu untuk data tertentu seperti laporan hasil rekonsiliasi

e. Pada Kanwil Propinsi Jakarta untuk meningkatkan kecenderungan untuk menyukai aplikasi SPAN dan penerimaan SPAN secara mental dapat dilakukan dengan meningkatkan Performance Expectancy. Berdasarkan saran operator 
SPAN pada Kanwil Propinsi Jakarta, hal ini dapat dilakukan dengan :

1) Dibuat user friendly dan peningkatan kapasitas akses, seperti kecepatan dalam approve transaksi penerimaan negara

2) SPAN agar menampung laporan yang dibutuhkan KPPN seperti pengawasan UP/TUP, uang muka

3) Penggantian perangkat komputer yang rusak segera direalisasikan

4) Penyederhaaan proses SPAN (terlalu banyak alur dan klik) untuk mengurangi kesalahan input data. Dan dilakukan perbaikan berkala tentang proses SPAN disesuaikan dengan dinamika pekerjaan

5) Peningkatan fasilitas pendukung SPAN seperti buku saku SPAN, kamus tentang notifikasi penolakan pendaftaran supplier, PMRT beserta pemecahannya

6) Diadakan pelatihan secara berkala

7) Kemudahan koordinasi dan komunikasi dengan pusat ketika ada permasalahan dan penyampaikan saran-saran perbaikan

f. Pada Kanwil Propinsi Riau untuk meningkatkan kecenderungan untuk menyukai aplikasi SPANdan penerimaan SPAN secara mental dapat dilakukan dengan meningkatkan Effort Expectancy. Berdasarkan saran operator SPAN pada Kanwil Propinsi Riau, hal ini dapat dilakukan dengan :

1) Pembuatan manual book penggunaan SPAN secara rinci dan melakukan diklat secara intensif

2) Penambahan user pada setiap seksi

3) SPAN diperbaharui dan dipermudah untuk mendapatkan data dari aplikasi SPAN khususnya dalam pembuatan laporan dan monitoring satker sehingga laporan yang disampaikan lebih akurat dan pengawasan satker lebih efektif.

g. Pada Kanwil Propinsi Sulawesi Selatan untuk meningkatkan kecenderungan untuk menyukai aplikasi SPAN dan penerimaan SPAN secara mental dapat dilakukan dengan meningkatkan Performance Expectancy. Berdasarkan saran operator SPAN pada Kanwil Propinsi Sulawesi Selatan, hal ini dapat dilakukan dengan :

1) Peningkatan keandalan Aplikasi SPAN yang dapat memenuhi segala kebutuhan laporan pada KPPN dan pusat, sehingga tidak perlu lagi mengolah data yang sebenarnya sudah ada di SPAN sesuai konsep Singgle Database

2) Diperlukan FAQ dan manual book yang disesuaikan dengan SOP pada KPPN.

3) Peningkatan kualitas jaringan internet.

4) Perlu dibangun prosedur manual di luar SPAN untuk mengantisipasi terhentinya operasionalisasi SPAN yang terhenti karena gangguan internet, listrik, komputer, sehingga layanan kepada pengguna tidak terhenti. Ketika sistem kembali normal ada mekanisme untuk memindahkan prosedur manual ke dalam sistem SPAN.

h. Pada Kanwil Propinsi Sumatera Utara untuk meningkatkan kecenderungan untuk menyukai aplikasi SPAN dapat dilakukan dengan meningkatkan Effort Expectancy, sedangkan untuk meningkatkan penerimaan SPAN secara mental dapat dilakukan dengan meningkatkan Social Influence. Berdasarkan saran operator SPAN pada Kanwil Propinsi Sumatera Utara, hal ini dapat dilakukan dengan :

1) Peningkatan inftrastruktur seperti server, koneksi internet, saat ini untuk mengunduh laporan memerlukan waktu satu hari

2) Penambahan user atau diperkenankan adanya perangkapan user untuk mengantisipasi kalau user yang bersangkutan cuti atau dinas luar

3) Karena aplikasi SPAN sulit dilakukan perubahan mendasar sebaiknya fokus pada stabilitas koneksi dan memaksimalkan aplikasi penunjang misalnya OMSPAN

4) Data di OMSPAN agar cepat diupdate agar sama antara aplikasi SPAN dan OMSPAN

5) Penambahan fasilitas penyusunan laporan keuangan BUN daerah.

i. Pada Kanwil Propinsi Tanjung Pinang untuk meningkatkan kecenderungan untuk menyukai aplikasi SPAN dan penerimaan SPAN secara mental dapat dilakukan dengan meningkatkan Social Influence. Berdasarkan saran operator SPAN pada Kanwil Propinsi Tanjung Pinang, hal ini dapat dilakukan dengan :

1) Countinous improvement dalam penyempurnaan apllikasi SPAN

2) Peningkatan kapasitas server dan jaringan agar tidak terjadi down atau trouble saat pekerjaan overload. 
3) Diadakan edukasi dan pelatihan secara berkala terhadap operator SPAN

4) Perlu manual book yang update dan komprehensif

j. Pada Kanwil Propinsi Yogyakarta untuk meningkatkan kecenderungan untuk menyukai aplikasi SPAN dapat dilakukan dengan meningkatkan Social Influence, sedangkan untuk meningkatkan penerimaan SPAN secara mental dapat dilakukan dengan meningkatkan Facilitating Conditions. Berdasarkan saran operator SPAN pada Kanwil Propinsi Yogyakarta, hal ini dapat dilakukan dengan :

1) Infrastruktur jaringan dan koneksi internet agar lebih ditingkatkan

2) Diadakan diklat / training secara rutin

\section{DAFTAR PUSTAKA (REFERENCES)}

Ajzen, I. (1991). The theory of planned behavior. Organizational Behavior and Human Decision Processes.

A.N. Parr \& Dr.G. Shanks, (2000) A Taxonomi of ERP Implementation Approach, Proceeding of 33rd Hawai International Conference on System Sciences

Barker, T. and M. Frolick (2003). ERP implementation failure: a case study, Information Systems Management

Boudreau, M.C (2002) "Learning to use ERP technology a causal model", Proceeding of 36th Hawaii International Conference System of Science.

Davis, F. D. (1989). Perceived usefulness, perceived ease of use, and user acceptance of information technology. MIS Quarterly.

Davenport, Thomas H, (1998) Putting the Enterprise in Enterprise System, Harvard Business Review.

Ditjen Perbendaharaan dan IPB,(2015) Survey tingkat kepuasan user terhadap implementasi SPAN.

Haryono, Siswono dan Parwoto Wardoyo, (2013), Structural Equation Model, PT Intermedia Personalia Utama, Bekasi

Kuncoro, Mudrajad, (2013) Netode Kuantitatif : Teori dan Aplikasi untuk Bisnis dan Ekonomi, UPP STIM YKPN, Yogyakarta
Noviaristanti, Siska, (2006) Model Penerimaan Sistem ERP (system acceptance) pada fase post project

Nah, F.F.H, Tan, X, Teh, S.H (2004), An Empericical Investigation on End User Acceptance of Enterprise Systems, dalam Information Resources Management Journal, Vol 17, No.3.

Panggabean, Mutiara (2004), "Manajemen Sumber Daya Manusia", Jakarta : Ghalia Indonesia.

Scott, Judy E \& Vessey Iris, Managing Risks in Enterprise System Implementations, Indiana University's Kelly School of Business

Umble, E.J.R.R Haft and M.M Umble (2003) "Enterprise Resource Planning : Implementation Procedures and Critical Success Factors "European Journal of Operational Research"

Venkatesh, V., \& Davis, F. D. (2000). A theoretical extension of the technology acceptance model: Four longitudinal filed studies. Management Science. 


\section{ILUSTRASI TABEL}

Tabel 1.

Tabel Hasil SEM Wilayah Bali, Jateng, Banten dan Papua

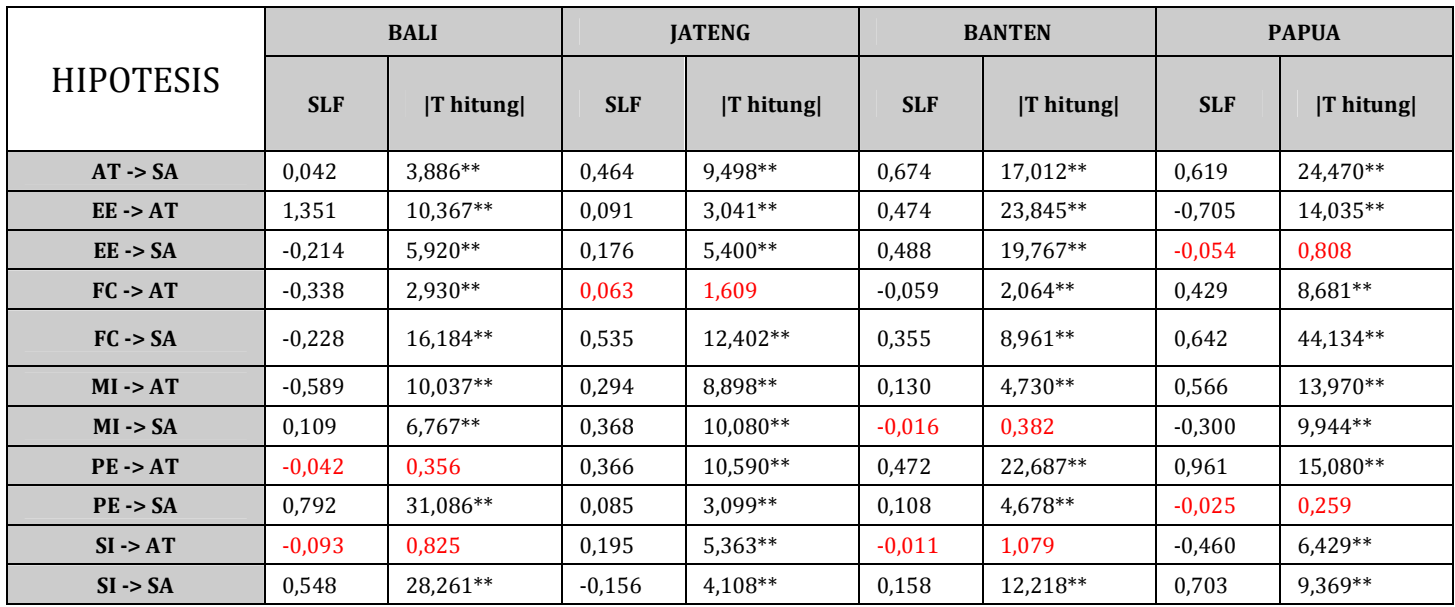

Keterangan : ${ }^{* *}$ ) significant at level $5 \%$

Tabel .2

Tabel Hasil SEM Wilayah Jakarta, Riau dan Sulawesi

\begin{tabular}{|c|c|c|c|c|c|c|}
\hline \multirow{2}{*}{ HIPOTESIS } & \multicolumn{2}{|c|}{ JAKARTA } & \multicolumn{2}{|r|}{ RIAU } & \multicolumn{2}{|c|}{ SULAWESI } \\
\hline & SLF & |T hitung| & SLF & |T hitung| & SLF & |T hitung| \\
\hline $\mathrm{AT}->\mathrm{SA}$ & 0,487 & $12,218^{* *}$ & 0,310 & $10,949^{* *}$ & 0,736 & $24,706^{* *}$ \\
\hline $\mathrm{EE} \rightarrow \mathrm{AT}$ & 0,168 & $3,286^{* *}$ & 0,684 & $22,352^{* *}$ & 0,405 & $8,657^{* *}$ \\
\hline$E E->S A$ & $-0,004$ & 0,106 & 0,943 & $40,085^{* *}$ & 0,412 & $8,905^{* *}$ \\
\hline $\mathrm{FC} \rightarrow \mathrm{AT}$ & 0,225 & $4,835^{* *}$ & $-0,069$ & $2,319 * *$ & $-0,141$ & $2,384^{* *}$ \\
\hline$F C \rightarrow S A$ & 0,301 & $6,539 * *$ & $-0,071$ & $3,189^{* *}$ & 0,000 & 0,004 \\
\hline MI $\rightarrow$ AT & 0,251 & $6,777^{* *}$ & 0,124 & $2,179 * *$ & $-0,258$ & $5,384^{* *}$ \\
\hline MI $->$ SA & 0,123 & $3,313^{* *}$ & 0,113 & $4,734^{* *}$ & 0,113 & $2,670^{* *}$ \\
\hline PE $\rightarrow$ AT & 0,322 & $9,406^{* *}$ & 0,031 & 0,683 & 0,597 & $12,061^{* *}$ \\
\hline$P E->S A$ & 0,438 & $12,288^{* *}$ & $-0,215$ & $10,343^{* *}$ & 0,442 & $11,193^{* *}$ \\
\hline SI $\rightarrow A T$ & 0,042 & 1,269 & 0,211 & $6,358^{* *}$ & 0,260 & $5,416^{* *}$ \\
\hline SI $>$ SA & 0,158 & $4,367^{* *}$ & 0,237 & $14,622^{* *}$ & 0,144 & $4,514^{* *}$ \\
\hline
\end{tabular}

Keterangan : ${ }^{* *}$ ) significant at level $5 \%$ 
Tabel 3

Tabel Hasil SEM Sumatera Utara, Tanjung Pinang dan Yogyakarta

\begin{tabular}{|c|c|c|c|c|c|c|}
\hline \multirow{2}{*}{ HIPOTESIS } & \multicolumn{2}{|c|}{ SUMUT } & \multicolumn{2}{|c|}{ TANJUNGPINANG } & \multicolumn{2}{|c|}{ YOGYA } \\
\hline & $\begin{array}{c}\text { Original } \\
\text { Sample (0) }\end{array}$ & $\begin{array}{c}\text { T Statistics } \\
\text { (|0/STERR|) }\end{array}$ & $\begin{array}{c}\text { Original } \\
\text { Sample (0) }\end{array}$ & $\begin{array}{c}\text { T Statistics } \\
\text { (|0/STERR } \mid)\end{array}$ & $\begin{array}{c}\text { Original } \\
\text { Sample (0) }\end{array}$ & $\begin{array}{c}\text { T Statistics } \\
\text { (|0/STERR|) }\end{array}$ \\
\hline AT $->$ SA & 0,891 & $12,668^{* *}$ & 0,311 & $19,162^{* *}$ & 0,622 & $23,811^{* *}$ \\
\hline EE $->$ AT & 0,467 & $22,298^{* *}$ & $-0,235$ & $5,018^{* *}$ & 0,365 & $5,581^{* *}$ \\
\hline EE $->$ SA & 0,410 & $12,915^{* *}$ & $-0,452$ & $19,532^{* *}$ & 0,416 & $7,478^{* *}$ \\
\hline FC $\rightarrow$ AT & 0,178 & $10,281^{* *}$ & $-0,031$ & 0,339 & $-0,264$ & $2,054^{* *}$ \\
\hline FC $->$ SA & 0,322 & $8,427 * *$ & 0,272 & $8,281^{* *}$ & 1,053 & $21,273^{* *}$ \\
\hline MI $->$ AT & $-0,012$ & 0,646 & 0,401 & $6,426^{* *}$ & 0,305 & $3,216^{* *}$ \\
\hline MI -> SA & $-0,147$ & $8,012^{* *}$ & 0,041 & 1,780 & $-0,597$ & $21,020^{* *}$ \\
\hline PE $->$ AT & 0,113 & $7,059^{* *}$ & 0,236 & $9,345^{* *}$ & $-0,445$ & $8,887^{* *}$ \\
\hline PE $->$ SA & 0,083 & $2,915^{* *}$ & 0,269 & $20,619^{* *}$ & 0,068 & $3,428^{* *}$ \\
\hline SI $->$ AT & 0,376 & $15,812^{* *}$ & 0,715 & $10,726^{* *}$ & 0,922 & $10,756^{* *}$ \\
\hline $\mathrm{SI} \rightarrow \mathrm{SA}$ & 0,366 & $14,017^{* *}$ & 0,927 & $44,812^{* *}$ & 0,011 & 0,288 \\
\hline
\end{tabular}

Keterangan : ${ }^{* *}$ ) significant at level $5 \%$ 


\section{ILUSTRASI GRAFIK}

Gambar 1.
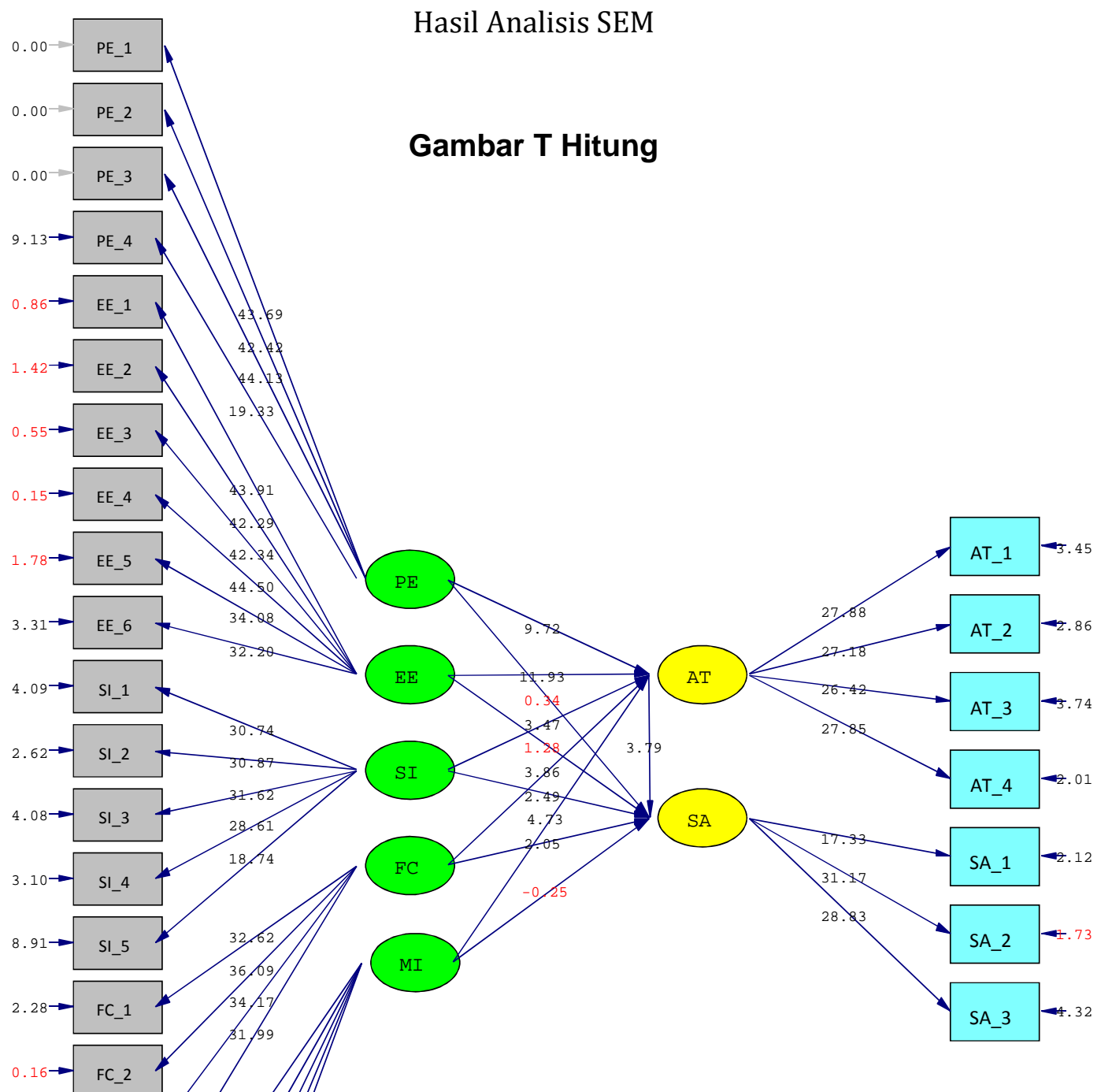

$0.16 \rightarrow$ FC_2

$0.50 \rightarrow$ FC_3

$1.55 \rightarrow$ FC_4

$1.31 \rightarrow$ MI_1

$8.87 \rightarrow$ MI_2

$4.82 \rightarrow$ MI_3

4.15 $\rightarrow$ MI_4

$7.96 \rightarrow$ MI_5

Chi-Square $=358.22, \mathrm{df}=385, \mathrm{P}-\mathrm{value}=0.83251, \mathrm{RMSEA}=0.000$ 


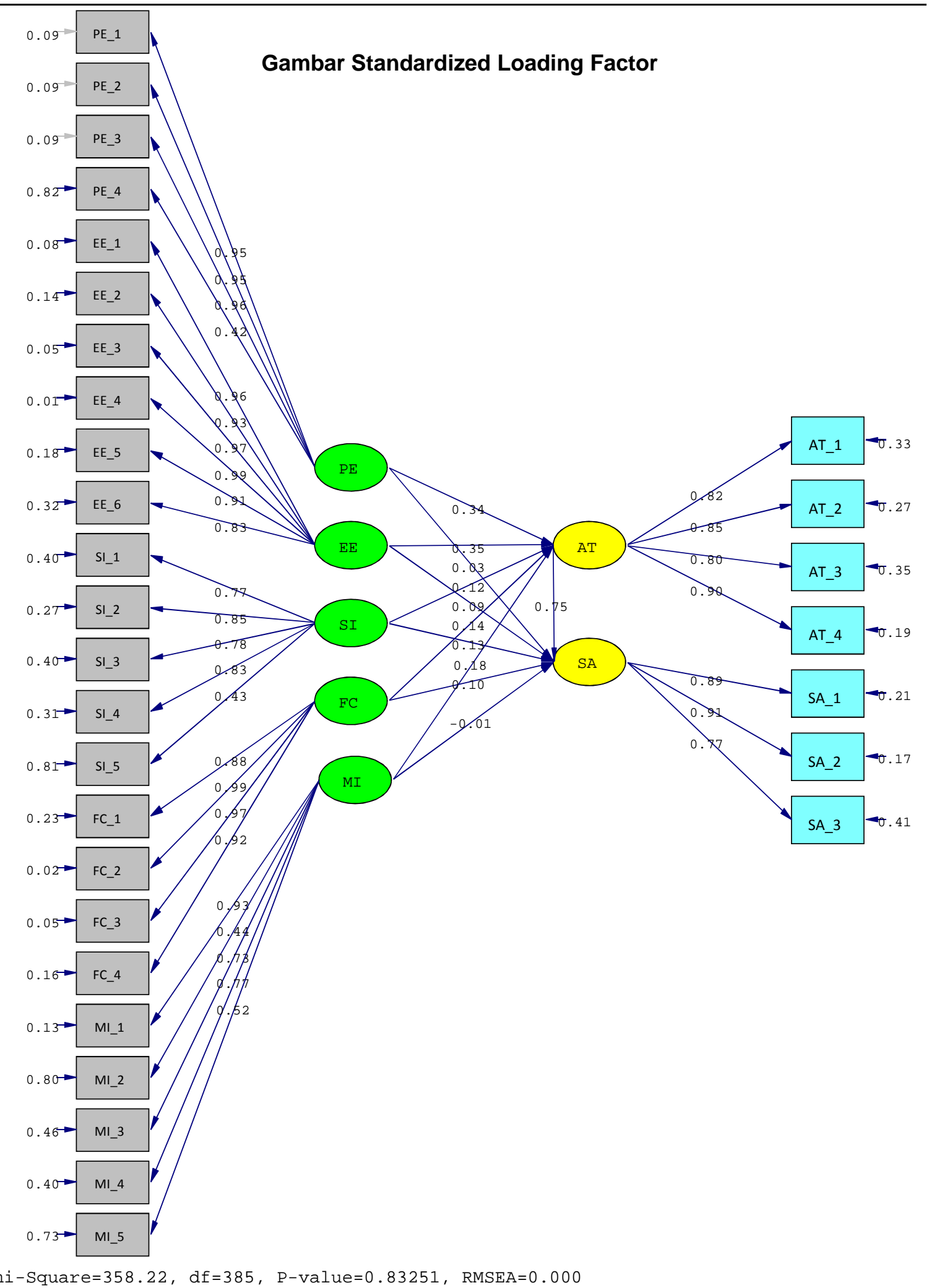

